AgniesZKa Kania ${ }^{1}$

\title{
Prawo do pochówku nasciturusa w świetle praw człowieka
}

\section{Wprowadzenie}

Regulacje prawne dotyczące dziecka poczętego, ale jeszcze nie narodzonego, dotykają sfery niezwykle newralgicznej, szczególnie jeżeli poddaje się w tym kontekście analizie normy odnoszące się do praw człowieka, które z natury rzeczy są przyrodzone.

Punktem wyjścia poniższych rozważań pozostaje prawo do pochówku, które zalicza się do kategorii dóbr osobistych i jest ściśle związane z tzw. prawem do grobu, ale nie o charakterze majątkowym, a przede wszystkim mającym postać niemajątkową. Prawo do pochówku powinno być rozpatrywane $\mathrm{w}$ dwóch płaszczyznach, wyróżnionych ze względu na podmiot, któremu z mocy prawa przysługuje, a mianowicie osobę zmarłą oraz najbliższą rodzinę zmarłego. Zadaniem stojącym przed niniejszym opracowaniem będzie więc rozstrzygnięcie problemu statusu prawnego nasciturusa i jego prawa do pochówku wypływającego z praw człowieka lub z prawa przysługującego rodzicom oraz osobom bliskim dziecka utraconego. Na płaszczyźnie praw człowieka zostanie podjęta próba wyjaśnienia, czy godność jako prawo podstawowe przysługuje także nasciturusowi, skąd powinna wypływać ochrona jego istnienia oraz prawa do godnej śmierci i godnego pochówku. Tym samym mająca swoje źródło w aktach rangi międzynarodowej i Konstytucji $\mathrm{RP}^{2}$ godność stanowić będzie wspólny mianownik do interpretacji wszelkich zmian prawnych chroniących nascituru$s a$, a w konsekwencji także dziecko martwo urodzone.

Całość rozważań pozwoli na sformułowanie postulatów de lege feren$d a$, dotyczących pochówku i statusu dziecka poczętego, oraz wyciągnięcie wniosków o przysługujących nasciturusowi fundamentalnych prawach. Wspomniane prawa znajdują wyraz w regulacji administracyjnoprawnej

1 Agnieszka Kania, studentka, Instytut Prawa Administracji i Ekonomii, Uniwersytet Pedagogiczny im. Komisji Edukacji Narodowej w Krakowie.

2 Konstytucja Rzeczypospolitej Polskiej z dnia 2 kwietnia 1997 r., Dz.U. Nr 78, poz. 483 ze zm., dalej: Konstytucja RP. 
i odnoszą się do zmian danych wymaganych do wydania aktu urodzenia dziecka $\mathrm{z}$ adnotacją o martwym urodzeniu, która stanowiła podstawę do przyjęcia na cmentarz dziecka martwo urodzonego.

Dzięki zastosowaniu metody formalno-dogmatycznej prezentowane rozważania pozwolą na analizę stanu prawnego de lege lata ustawy z dnia 31 stycznia 1959 r. o cmentarzach i chowaniu zmarlych ${ }^{3} \mathrm{w}$ zakresie wydania karty zgonu dziecka utraconego oraz przyjęcia na cmentarz i pochówku przez pryzmat doktryny prawniczej. Uzupełniająco analiza prawna zostanie poparta twierdzeniami nauk medycznych i przywołaniem odpowiednich koncepcji filozoficznych. Metodę historyczno-prawna zastosowano w celu przedstawienia sytuacji prawnej dziecka martwo urodzonego sprzed dokonanych nowelą z 2011 r. zmian ustawowych. Ostatecznie analiza orzecznictwa sądowego wydanego pod rządami poprzednio obowiązującej ustawy pozwoli na ocenę prawidłowości wprowadzonej nowelizacji.

\section{Problem godności dziecka poczętego, ale jeszcze nie narodzonego}

Akty prawa międzynarodowego i Konstytucja RP nie są jednolite w określaniu cech godności. Powszechna Deklaracja Praw Człowieka ${ }^{4}$ zwraca uwagę na równość godności wszystkich ludzi (art. 1). Według Karty Praw Podstawowych $\mathrm{UE}^{5}$ i Konstytucji RP godność ma charakter nienaruszalny (art. $1 \mathrm{KPP}$, art. 30 Konstytucji RP). Dalej konstytucyjna definicja godności wymienia jej niezbywalność, ale zarazem przyrodzoność. Ta ostatnia cecha wypływa także z art. 10 i preambuły Międzynarodowego Paktu Praw Obywatelskich i Politycznych ${ }^{6}$. Natomiast zdaniem KPP godność jest dobrem ponadstanowionym, władza państwowa jej nie kreuje, a tylko jest zobowiązana do ochrony godności i jej poszanowania (art. 1 KPP). Na płaszczyźnie europejskiej również Konwencja o ochronie praw człowieka i podstawowych wolności ${ }^{7}$ w Protokole nr 13 mówi o wrodzonej godności wszystkich istot ludzkich.

W kontekście praw człowieka przynależnych dziecku poczętemu istnieje więc rozbieżność, jeśli chodzi o nasciturusa. Interpretacja tych aktów prawnych, które stanowią o cesze przyrodzoności godności (w tym Konstytucji $\mathrm{RP}$ ), pozwala przyznać nasciturusowi tylko godność wtórną, zależną od momentu narodzin. Natomiast $\mathrm{z}$ analizy KPP wynika, że godność nie może

3 Tekst jedn.: Dz.U. z 2019 r. poz. 1473 ze zm., dalej: u.c.ch.z.

4 Zob.http://www.unesco.pl/fileadmin/user_upload/pdf/Powszechna_Deklaracja_ Praw_Czlowieka.pdf (dostęp: 7.04.2019).

5 Dz.Urz. UE z 2016 r. C 202, s. 389, dalej: KPP.

6 Międzynarodowy Pakt Praw Obywatelskich i Politycznych otwarty do podpisu w Nowym Jorku dnia 19 grudnia 1966 r., Dz.U. z 1977 r. Nr 38, poz. 167.

7 Konwencja o Ochronie Praw Człowieka i Podstawowych Wolności sporządzona w Rzymie dnia 4 listopada 1950 r., zmieniona następnie Protokołami nr 3, 5 i 8 oraz uzupełniona Protokołem nr 2, Dz.U. z 1993 r. Nr 61, poz. 284, dalej: EKPC. 
być przez państwo przyznana istocie ludzkiej biorącej swój początek, jak to określa polska cywilistyka, od rodziców, którzy są ludźmi ${ }^{8}$. Jednak przepisy KPP w Polsce stosuje się tylko w zakresie, który określają normy prawa wewnętrznego, prawa Unii Europejskiej lub wiążące akty prawne o charakterze międzynarodowym ${ }^{9}$, dlatego nie można rozszerzać $\mathrm{w}$ tym przypadku zakresu godności także na nasciturusa. Inny charakter mają postanowienia EKPC, które nie stanowią o przyrodzonej, a wrodzonej godności jednostki ludzkiej. Pojęcie wrodzoności cechuje szerszy zakres semantyczny niż pojęcie przyrodzoności. Dlatego też na podstawie art. 9 Konstytucji RP, nakazującego Rzeczypospolitej Polskiej „przestrzeganie wiążącego ją prawa międzynarodowego", należy stwierdzić, że wrodzoność godności odnosi się także do nasciturusa. Za takim rozumieniem opowiada się polskie ustawodawstwo, które przyznaje dziecku poczętemu szereg praw i zapewnia mu ochronę, np. dziecko poczęte może dziedziczyć spadek, z tym zastrzeżeniem, że musi przyjść na świat żywe (art. $927 \$ 2$ k.c. ${ }^{10}$ ). Zgodnie z cechą przyrodzoności „przesłanką warunkującą posiadanie godności są tu narodziny. Jednak taka interpretacja kłóci się z cechami niezbywalności i niepodzielności godności, która musiałaby wynikać z jakiegoś faktu, którym jest urodzenie, a nie przynależeć każdemu w pełni i w sposób obiektywny, oderwany od uznania. W innym ujęciu byłaby ona nadana przez arbitralną władzę państwową, decydującą w trakcie narodzin o tym, kto może na godność się powołać. Nie byłaby ona przynależna od samych początków życia. Dokumenty międzynarodowe nie mówią nic na temat, czy godność miałaby w takim przypadku przynależeć tylko jednostce ludzkiej, która przyjdzie na świat żywa, czy także dziecku martwo urodzonemu"1.

Niepewny status dziecka poczętego, wynikający ze szczególnej fazy życia i koncepcji warunkowej zdolności prawnej, wypływa z nieostrości pojęć życia ludzkiego i braku legalnej definicji człowieka ${ }^{12}$. Nie można więc bez wątpliwości rozstrzygnąć zamysłu ustawodawcy co do statusu nasciturusa tylko na gruncie prawnym. Należy odwołać się tutaj pomocniczo do nauk pozaprawnych. Według definicji medycznych człowiek jest istotą mającą

8 Z. Radwański, A. Olejniczak, Prawo cywilne - część ogólna, Warszawa 2017, s. $152-153$.

9 M. Jaśkowski, Konsekwencje prawne Protokołu nr 30 w sprawie stosowania Karty praw podstawowych Unii Europejskiej do Polski i Zjednoczonego Królestwa, „Zeszyty Prawnicze" 2013, nr 4 (40), s. 33.

10 Ustawa z dnia 23 kwietnia 1964 r. - Kodeks cywilny, tekst jedn.: Dz.U. z 2019 r. poz. 1145 ze zm.

11 A. Kania, Nasciturus pro iam nato habetur... dziecko (nasciturus) czy kobieta? Przesłanki przerwania ciąży w kontekście praw człowieka - analiza prawna [w:] Powszechny system ochrony praw człowieka 70 lat po proklamowaniu Powszechnej Deklaracji Praw Człowieka. Osiagnięcia - bariery - nowe wyzwania i rozwiązania, J. Jaskiernia, K. Spryszak (red.), Toruń 2019, s. 358-359.

12 M. Zubik, Ochrona prawna początku życia człowieka w rozwiąaniach międzynarodowych i konstytucyjnych w Europie, „Przegląd Sejmowy” 2007, nr 3 (80), s. 21. 
swój własny genotyp i fenotyp, która powstaje w sposób ciągly, od momentu koncepcji, czyli połączenia męskiej i żeńskiej gamety ${ }^{13}$. W polskim orzecznictwie na kontinuum życia ludzkiego zwraca uwagę stanowisko odrębne do wyroku TK sędziego W. Sokolewicza ${ }^{14}$. Także filozofia nadaje wprost godność osobową dziecku poczętemu, znajdując jej źródło w „spójności i nierozerwalności różnych etapów ludzkiego istnienia" i wskazując wyłącznie na kryterium biologiczne dla przyznania statusu osoby ${ }^{15}$. Ponadto przyjmuje się, że etapy rozwoju człowieka $\mathrm{w}$ fazie postnatalnej zaczynają kształtować się już w fazie życia płodu ${ }^{16}$.

Posiłkując się stanowiskiem nauk medycznych i filozoficznych, jak również polskiego orzecznictwa, należy stwierdzić, że godność nasciturusowi przysługiwać powinna, ponieważ jest on istotą ludzką, a w przyszłości ma prawo stać się pełnoprawnym człowiekiem (koncepcja potencjalnej osoby moralnej ${ }^{17}$ ). W szczególności godność będzie przysługiwać dziecku martwo urodzonemu. Przemawia za tym wykładnia literalna norm prawnych, mówiąca o martwym urodzeniu dziecka, nie nasciturusa, a jak wcześniej wskazano, z momentem narodzin godność przysługuje już w pełni. Tym samym ani Konstytucja RP, ani inne akty międzynarodowe nie różnicują godności ze względu na martwe lub żywe urodzenie, ewentualnie uzależniają jej posiadanie od momentu urodzenia, co jak wskazano wyżej jest dyskusyjne.

\section{Prawo do pochówku w polskim systemie prawnym}

W polskim systemie prawnym prawo do pochówku zwłok ludzkich jest zaliczane do katalogu dóbr osobistych ${ }^{18}$, a tym samym podlega ochronie wynikającej z przepisów prawa cywilnego ${ }^{19}$. Katalog ten ma charakter otwarty $^{20}$, dlatego prawo do pochówku nie jest wprost wyartykułowane w art. 23 k.c., a jego źródła możemy poszukiwać w szerszym znaczeniowo prawie do grobu. Niemniej art. 24 k.c. gwarantuje w przypadku naruszenia lub zagrożenia naruszeniem prawa do pochówku takie same środki ochro-

13 A. Michajlik, W. Ramotowski, Anatomia i fizjologia człowieka, Warszawa 2015, s. 29; J. Fąk, Zarodek, płód, od kiedy człowiek? [w:] Aborcja w ujęciu prawa, medycyny i psychologii, D. Franków (red.), Siedlce 2005, s. 25.

14 Orzeczenie TK z dnia 28 maja 1997 r., K 26/96, Legalis nr 10361.

15 G. Hołub, Godność osobowa dziecka nienarodzonego, http://bc.upjp2.edu.pl/ Content/1756/holub-grzegorz.pdf (dostep: 7.4.2019), s. 17-18.

16 Ibidem.

17 J. Kis, Potencjalna osoba moralna - dziecko poczęte odczuwajace emocje (ok. 24 tydzień ciązy), noworodek [w:] Aborcja. Argumenty za i przeciw, Warszawa 1993, s. $140-142$.

18 P. Drembkowski, Ustawa o cmentarzach i chowaniu zmarlych. Komentarz, Warszawa 2018, s. 40.

19 Zob. art. 23 i 24 k.c.

20 I. Lewandowska-Malec, Dobra osobiste, wyd. 2, Warszawa 2017, Legalis. 
ny, jak w przypadku innych dóbr osobistych, a mianowicie zaniechanie bezprawnego działania, usunięcie skutków naruszenia, zadośćuczynienie pieniężne lub zapłatę odpowiedniej sumy pieniężnej na wskazany cel społeczny (art. 24 k.c.).

Treść prawa do grobu można scharakteryzować z jednej strony jako możność rozporządzenia mortis causa własnymi zwłokami, w szczególności polegające na określeniu miejsca i sposobu pochówku w formie testamentu, polecenia testamentowego lub niewiążącego prawnie życzenia, przybierającego wyłącznie charakter moralny ${ }^{21}$ (prawo do pochówku własnego). Z drugiej strony prawo do grobu to również wyrażone w art. 10 u.c.ch.z. prawo rodziny do pochowania zwłok osób bliskich, a także prawo do kultu pamięci po zmarłym, ochrony jego czci i prywatności ${ }^{22}$. Co za tym idzie uprawnienia osobiste na gruncie prawa do grobu przynależne są dwóm grupom podmiotów. Do pierwszej zalicza się osoba zmarła, która z momentem śmierci traci wraz z utratą zdolności prawnej podmiotowość prawną, ale prawo chroni dobra osobiste nabyte przez nią za życia, np. prawa autorskie, cześć czy prywatność, i realizuje rozrządzenia tej osoby na wypadek śmierci. Do drugiej grupy należy na mocy art. 10 u.c.ch.z. „najbliższa pozostała rodzina osoby zmarłej", a mianowicie pozostały małżonek, krewni zstępni, krewni wstępni, krewni boczni do 4 stopnia pokrewieństwa oraz powinowaci $\mathrm{w}$ linii prostej do 1 stopnia. Artykuł 10 u.c.ch.z. nie kreuje prawa do grobu ${ }^{23}$, a jedynie określa krąg osób uprawnionych i zobowiązanych do pochówku zmarłego ${ }^{24}$. W doktrynie podnosi się, że katalog wymieniony w art. 10 oparty jest na gradacji, czyli wykonywanie prawa do pochówku należy przede wszystkim do osoby wymienionej przez przepis w pierwszej kolejności. Osobom określonym $\mathrm{w}$ dalszej kolejności prawo to przysługuje jedynie w razie niewykonywania lub nieistnienia osoby wymienionej wcześniej ${ }^{25}$. Jednak sąd ze względu na niezgodne z powszechnie uznanymi stosunki rodzinne osoby zmarłej i zobowiązanej do pochówku może przyznać to prawo osobie określonej w dalszej kolejności ${ }^{26}$.

W kontekście nasciturusa, zgodnie z zasadami prawidłowego rozumowania i logiki oraz na gruncie zasad współżycia społecznego, niewłaściwe stosunki rodzinne mogłaby sugerować próba nielegalnego ${ }^{27}$ przerwania

21 K. Michałowska, Niemajątkowe wartości życia rodzinnego $w$ polskim prawie cywilnym, Warszawa 2017, Legalis.

22 Ibidem.

23 Wyrok SN z dnia 9 grudnia 2011 r., III CSK 106/11, Legalis nr 429214.

24 E. Darmorost, Ustawa o cmentarzach i chowaniu zmarlych. Komentarz, Warszawa 2014, s. 45.

25 P. Drembkowski, Ustawa..., s. 49.

26 Ibidem.

27 Niezgodnego z art. 4a ustawy z dnia 7 stycznia 1993 r. o planowaniu rodziny, ochronie płodu ludzkiego i warunkach dopuszczalności przerywania ciąży, Dz.U. $\mathrm{Nr} 17$, poz. 78 ze zm. 
ciąży przez matkę i ojca dziecka, wtedy prawo do pochówku przysługiwałoby dziadkom. Analogicznie należy kolejność pochówku rozpatrywać co do obowiązku pochowania osoby zmarłej ${ }^{28}$.

Prawo do pochówku należy do części składowych szerszego pojęcia prawa do grobu, które można rozpatrywać w aspekcie materialnym i niematerialnym. Orzecznictwo sądowe wskazuje, że uprawnienia majątkowe prawa do pochówku mają charakter drugorzędny i polegają na zbywalnym i dziedzicznym prawie do określonego miejsca na cmentarzu, ale tylko w przypadku nabycia i urządzenia grobu za życia i niezajęcia go przez inną oso$\mathrm{bę}^{29}$. Oznacza to, że w przypadku pochowania w danym grobie zwłok innej osoby samodzielne prawo majątkowe do grobu jednej osoby wygasa na rzecz nierozerwalnego zespolenia z prawem niemajątkowym innej osoby ${ }^{30}$. Zdaniem SN uprawnienia niemajątkowe to „pochowanie po śmierci zwłok uprawnionego w wybranym przez niego miejscu w grobie jednoosobowym lub wieloosobowym rodzinnym, obok zwłok osób mu bliskich" ${ }^{31}$. Ze względu na szczególną fazę życia nasciturus nie będzie mógł wprost zrealizować prawa do pochówku własnego. Dziecko poczęte nie jest w stanie dokonać samodzielnie rozrządzenia na wypadek śmierci. Jednak polskiemu prawu rodzinnemu jest faktycznie znana instytucja kuratora nasciturusa, która ustanawiana jest $\mathrm{w}$ celu zabezpieczenia przyszłych praw dziecka poczętego (art. 182 k.r.o. ${ }^{32}$ ). Ochroną kuratora objęte są te prawa warunkowe nasciturusa, które po narodzinach dziecko będzie mogło realizować, czyli zarówno prawa majątkowe, jak i niemajątkowe ${ }^{33}$. Tak więc ochrona warunkowego prawa do grobu i wchodzącego $\mathrm{w}$ jego zakres prawa do pochówku należy do kuratora ustanowionego w myśl art. 182 k.r.o. Hipotetycznie kurator mógłby dokonać rozrządzenia mortis causa pochówkiem zwłok dziecka martwo urodzonego, ale byłoby to tylko pośrednie wykonywanie prawa do pochówku własnego przez dziecko poczęte, gdyż de facto to kurator realizowałby swoją wizję pochówku, oddającą powszechnie przyjęte wzorce kulturowe. Instytucja kuratora nasciturusa wygasa $\mathrm{z}$ chwilą narodzin (art. 182 k.r.o.). Kurator także nie jest objęty zakresem podmiotowym art. 10 u.c.ch.z., dlatego ostatecznie prawo do pochówku dziecka martwo urodzonego realizować będą rodzice lub dalsza rodzina.

Aby wystąpił prawny obowiązek realizacji prawa do pochówku nasciturusa określonego przez kuratora, materializacja tego prawa musiałaby nastąpić przez polecenie testamentowe lub testament. Obecnie w polskim prawie nie ma możliwości sporządzenia testamentu i innych rozrządzeń

28 P. Drembkowski, Ustawa ..., s. 49.

29 Wyrok SN z dnia 3 grudnia 2010 r., I CSK 66/10, Legalis nr 414109.

30 Ibidem.

31 Ibidem.

32 Ustawa z dnia 25 lutego 1964 r. - Kodeks rodzinny i opiekuńczy, tekst jedn.: Dz.U. z 2017 r. poz. 682 ze zm.

33 T. Smyczyński, Prawo rodzinne i opiekuńcze, Warszawa 2016, s. 358-359. 
na wypadek śmierci przez przedstawiciela (art. $944 \$ 2$ k.c.), więc kurator nie może wykonać prawa do pochówku nasciturusa. Dla ścisłości wywodu trzeba zaznaczyć, że sporządzić testamentu nie może osoba niemająca pełnej zdolności do czynności prawnych (art. $944 \$ 1$ k.c.), a tym bardziej podmiot obdarzony tylko warunkową zdolnością prawną. Należałoby więc postulować wprowadzenie określonych zmian prawnych i udzielenie kuratorowi nasciturusa faktycznej możliwości ochrony wszystkich praw dziecka poczętego, także prawa do pochówku, ale praktyka nie widzi takiej potrzeby. Prawo do pochówku nigdy nie mogłoby być bowiem zrealizowane przez nasciturusa w pełni, a zakłady opieki zdrowotnej pośrednio wykonują prawo do pochówku dzieci martwo urodzonych, gdy rodzice lub rodzina nie mogą lub nie chcą tego zrobić, zazwyczaj przez złożenie zwłok dzieci martwo urodzonych w zbiorowym grobie na cmentarzu ${ }^{34}$. Podmioty $\mathrm{z}$ art. 10 u.c.ch.z. nie są zobowiązane do pochówku dziecka martwo urodzonego, odmienna wykładnia przepisu wiązałaby się $\mathrm{z}$ jednoznacznym przyznaniem nasciturusowi przez prawo polskie statusu osoby ludzkiej, co w obecnym stanie prawnym nie jest dopuszczalne, gdyż nasciturus jest objęty tylko warunkową zdolnością prawną.

Drugim aspektem prawa do grobu pozostaje „kult pamięci zmarłych, który polega na przysługujących człowiekowi różnych wolnościach, wypływających ze sfery uczuć i odczuć odnoszącej się do postaci osoby zmarłej, okazywania szacunku dla wspomnień i pamięci o niej, urządzenia pogrzebu oraz grobowca i decydowania o jego wystroju, załatwiania spraw z zarządem cmentarza, ochronie przed naruszeniami, składania wieńców, palenia zniczy, decydowania lub współdecydowania o przeznaczeniu wolnych miejsc w grobowcu dla pochowania dalszych zmarłych itp." ${ }^{35}$. W powyższym rozumieniu prawo do grobu do nasciturusa odnosi się w sposób przedmiotowy. Tak więc bezsprzecznie nasciturusowi przysługuje kult pamięci istnienia. Podmiotami tego prawa są w szczególności rodzice dziecka utraconego i jego pozostała najbliższa rodzina, czyli na mocy art. 10 u.c.ch.z. krewni wstępni i krewni boczni do 4 stopnia pokrewieństwa.

\section{Karta zgonu jako administracyjnoprawna podstawa realizacji prawa do pochówku}

Podstawę pochowania zwłok stanowi karta zgonu, wydawana najbliższej osobie zmarłego przez lekarza lub inną osobę powołaną przez właściwego starostę (art. 11 ust. 1 i 2 w zw. z ust. 4 u.c.ch.z.). Po zarejestrowaniu zgonu w urzędzie stanu cywilnego karta zgonu wraz $\mathrm{z}$ adnotacją o rejestracji

34 Dziecko martwo urodzone - czynności prawne, http://www.sluzew.dominikanie. pl/rodzice_dziecka_utraconego/img/dziecko_martwo_urodzone_czynnosci_prawne. pdf (dostęp: 6.04.2019).

35 Wyrok SN z dnia 3 grudnia 2010 r., I CSK 66/10. 
przekazywana jest administracji cmentarza i na tej podstawie dochodzi do przyjęcia na cmentarz zwłok osoby zmarłej (art. 11 ust. 4 b u.c.ch.z.). Pochowanie i przyjęcie na cmentarz zwłok dziecka martwo urodzonego następuje na podstawie karty zgonu, która wydawana jest na wniosek najbliższej rodziny dziecka utraconego (podmiotu $\mathrm{z}$ art. 10 u.c.ch.z.). Administracja cmentarza nie może żądać w tym przypadku przedstawienia adnotacji o rejestracji zgonu w urzędzie stanu cywilnego. Kartę wydaje się „bez względu na czas trwania ciąży" (art. 11 ust. 5a u.c.ch.z.).

Artykuł 11 ust. 5a u.c.ch.z. wszedł w życie 14 października 2011 r. w wyniku nowelizacji przepisów ustawy o cmentarzach i chowaniu zmarłych ${ }^{36}$. Dodanie tego przepisu było reakcją na potrzebę społeczną uregulowania nieścisłości stanu prawnego, na mocy art. 38 i 40 ustawy z dnia 29 września 1986 r. - Prawo o aktach stanu cywilnego ${ }^{37}$ administracja cmentarza dopuszczała bowiem pochówek dziecka martwo urodzonego wyłącznie na podstawie aktu martwego urodzenia dziecka ${ }^{38}$. Tak więc sporządzano tylko akt urodzenia dziecka $\mathrm{z}$ adnotacją o martwym urodzeniu i nie sporządzano aktu zgonu ${ }^{39}$. Wiązało się to z koniecznością wskazania płci dziecka, co niejednokrotnie ze względu na stan wiedzy medycznej lub koszty było niemożliwe ${ }^{40}$. W uzasadnieniu projektu ustawy o zmianie ustawy Prawo o aktach stanu cywilnego podnoszono, że dane dotyczące płci, ciężaru i długości ciała dziecka utraconego należy umieszczać w aktach stanu cywilnego, jeżeli jest to możliwe ${ }^{41}$. Przyczyną takiego stanu rzeczy był fakt, że „niejednokrotnie dochodzi do martwych urodzeń na bardzo wczesnym etapie ciąży, kiedy można mówić o ukształtowanym zarodku, jednakże z przyczyn obiektywnych nie jest możliwe ustalenie jego płci" ${ }^{42}$.

Problem w wydawaniu karty martwego urodzenia dziecka stanowiło rozporządzenie Ministra Zdrowia z dnia 21 grudnia 2010 r. w sprawie rodzajów i zakresu dokumentacji medycznej oraz sposobu jej przetwarzania ${ }^{43}$ w łącznej interpretacji z zasadami wykładni prawa odnoszącymi się do nakazu spójności systemu prawnego i racjonalności prawodawcy w tworze-

36 Ustawa z dnia 26 maja 2011 r. o zmianie ustawy o cmentarzach i chowaniu zmarłych, Dz.U. Nr 144, poz. 853.

37 Tekst jedn.: Dz.U. z 2018 r. poz. 2224 ze zm.

38 E. Darmorost, Ustawa..., s. 68.

39 Ibidem.

40 Ibidem; Stanowisko Zespołu Prawnego ws. wymogów karty martwego urodzenia Federacji na rzecz Kobiet i Planowania Rodziny, http://federa.org.pl/karta-martwego-urodzenia/ (dostęp: 5.04.2019).

41 Druk sejmowy nr 3941 Sejmu RP VI kadencji z 19.01.2011 r., http://orka.sejm. gov.pl/Druki6ka.nsf/0/BAC0DF460FF65CCDC1257849003B7988/\$file/3941.pdf (dostęp: 5.04.2019).

42 Ibidem.

43 Dz.U. Nr 252, poz. 1697 ze zm.; zob. Stanowisko Zespołu Prawnego ws. wymogów karty martwego urodzenia... 
niu norm prawnych ${ }^{44}$. W rozporządzeniu tym ${ }^{45}$ zdefiniowano poronienie i urodzenie martwe. Obie definicje składały się z tożsamych części składowych, wskazywały na konieczność wydalenia lub wydobycia (całkowitego wydalenia lub wydobycia - w przypadku urodzenia martwego) płodu z organizmu kobiety, o ile funkcje życiowe płodu już całkowicie ustały, płód nie oddychał, nie dawał innych dowodów życia, takich jak czynność serca, tętnienie pępowiny czy świadome skurcze mięśni (pkt 2 i 4 załącznika). Czynnikiem rozgraniczającym poronienie i martwe urodzenie był czas. Z poronieniem mieliśmy do czynienia, o ile przesłanki definicji ziściły się „przed upływem 22 tygodnia ciąży (21 tygodni i 6 dni)”. Natomiast martwe urodzenie miało miejsce „po upływie 22 tygodnia ciąży” (pkt 2 i 4 załącznika). W obecnym stanie prawnym dokonano zmiany czynnika czasu, poronienie następuje „przed upływem 22. tygodnia ciąży (21 tygodni i 7 dni)”, a z martwym urodzeniem mamy do czynienia w pierwszym dniu 23 tygodnia ciąży, czyli po upływie 22 tygodnia od koncepcji ${ }^{46}$.

Konsekwencją powyższego rozróżnienia było błędne rozszerzanie zakresu pojęć poronienia i martwego urodzenia wpisywanych do dokumentacji medycznej, co miało wpływ na wydanie karty martwego urodzenia dziecka, stanowiącej podstawę złożenia zwłok zmarłego dziecka na cmentarzu ${ }^{47}$. Obowiązek wydania karty martwego urodzenia dziecka nie miał swojego źródła w dokumentacji medycznej, a w Prawie o aktach stanu cywilnego ${ }^{48}$. Za taką interpretacją przepisów opowiadało się orzecznictwo sądów powszechnych, gdzie stwierdzano, że dziecku martwo urodzonemu należy się godny pochówek, a śmierć nie odbiera nasciturusowi tego pra$\mathrm{wa}^{49}$. W orzecznictwie przyznawano możliwość pochówku dziecku utraconemu bez względu na stopień rozwoju i czas trwania ciąży, którego podstawę stanowił akt martwego urodzenia ${ }^{50}$.

44 Zob. Stanowisko Zespołu Prawnego ws. wymogów karty martwego urodzenia...

45 Załącznik nr 1 do rozporządzenia z dnia 21 grudnia 2010 r. w sprawie rodzajów, zakresu i wzorów dokumentacji medycznej oraz sposobu jej przetwarzania.

46 Zob. załącznik nr 1 do rozporządzenia Ministra Zdrowia z dnia 9 listopada 2015 r. w sprawie rodzajów, zakresu i wzorów dokumentacji medycznej oraz sposobu jej przetwarzania, Dz.U. poz. 2069.

47 J. Haberko, Konsekwencje prawne żywego i martwego urodzenia, „Prawo i Medycyna” 2007, nr 3, s. 75; Stanowisko Zespołu Prawnego ws. wymogów karty martwego urodzenia...

48 Ibidem.

49 Wyrok Sądu Rejonowego dla Warszawy Pragi-Południe z dnia 17 lutego 2016 r., VI U 462/15, http://orzeczenia.ms.gov.pl.

50 Wyrok Sądu Okręgowego w Piotrkowie Trybunalskim z dnia 27 listopada 2011 r., I C 1760/13 oraz wyrok Sądu Apelacyjnego w Rzeszowie z dnia 25 października 2012 r., I ACa 352/12, http://orzeczenia.ms.gov.pl. 


\section{Podsumowanie}

Przyznanie godności dziecku poczętemu, ale jeszcze nie narodzonemu jest źródłem także innych uprawnień, które w obecnym stanie prawnym niewątpliwie już ono posiada. Nie mogłaby istnieć tak szeroko ujmowana instytucja kuratora nasciturusa, jeżeli dziecko poczęte nie chroniłaby godność, będąca źródłem wszelkich praw i wolności (art. 30 Konstytucji RP). Ustawodawca bierze pod ochronę godność dziecka poczętego przez ochronę innych praw człowieka przynależnych nasciturusowi. Chroni np. prawo do życia, regulując możliwości legalnego przerwania ciąży w ustawodawstwie zwykłym, czy też prawo własności i inne prawa rzeczowe przez warunkowe dziedziczenie. Konkludując, posiadanie godności przez nasciturusa nie jest rozstrzygnięte wprost i wydaje się, że prawodawca powinien $\mathrm{w}$ tak ważnej kwestii wypowiedzieć się w przepisach prawa.

Jednak abstrahując od koncepcji godności czy warunkowej godności nasciturusa, należy stwierdzić, że dziecko martwo urodzone taką godność $\mathrm{i}$ inne fundamentalne prawa już posiada w pełni, skąd wynika jego prawo do godnego pochówku. Można więc stwierdzić, że nasciturusowi, podobnie jak już ukształtowanej i żyjącej osobie, powinno przysługiwać prawo do grobu w ujęciu podmiotowym i przedmiotowym. Dziecko poczęte nie jest tylko przedmiotem prawa rodziców i innych bliskich osób do kultu pamięci po jego istnieniu, ale jest także podmiotem własnego prawa do pochowku. Nasciturus, a w konsekwencji dziecko martwo urodzone, nie jest jednak $\mathrm{w}$ stanie $\mathrm{w}$ pełni zrealizować przynależnego mu prawa do pochówku, ponieważ nie może jeszcze wyrazić własnych uczuć, pragnień i dokonać prawnie skutecznych rozrządzeń na wypadek śmierci. Jednak pewną stabilność i ochronę prawa do grobu nasciturusa mógłby realizować kurator, gdy rodzice i pozostałe osoby bliskie dziecka martwo urodzonego nie są $\mathrm{w}$ stanie przeprowadzić godnego pochówku. Zatem należałoby dokonać nowelizacji w zakresie uprawnień kuratora dziecka poczętego i zezwolić mu na przygotowanie godnego pochówku dla nasciturusa. Ze względu na marginalną rolę i powoływanie kuratora tylko w sytuacjach wyjątkowych, gdy rodzice nie mogą należycie zabezpieczyć praw nienarodzonego ${ }^{51}$, wprowadzenie takiej zmiany prawnej nie wydaje się jednak możliwe.

Reasumując powyższy wywód, należy podkreślić, że dziecko martwo urodzone ma prawo do godnego pochówku bez względu na czas trwania ciąży matki. Tak więc dokonana nowelizacja i zastąpienie wymaganego do przyjęcia na cmentarz aktu martwego urodzenia dziecka kartą zgonu bez konieczności rejestracji w urzędzie stanu cywilnego ustabilizowały obowiązujący stan prawny w zakresie pochówku dzieci martwo urodzonych. Nowelizacja ta odpowiada także wymogom spójności systemu prawnego i objęcia ochroną państwa praw człowieka jak najszerszego grona istot

51 T. Smyczyński, Prawo rodzinne..., s. 358. 
ludzkich (realizacja postulatu „wrodzonej godności każdej istoty ludzkiej” z Protokołu nr 13 Konwencji o ochronie praw człowieka i podstawowych wolności przez objecie zakresem tego pojęcia dzieci martwo urodzonych).

Wątpliwości w obecnym stanie prawnym może budzić rozróżnienie pojęć poronienia i martwego urodzenia w dokumentacji medycznej. Aby zrealizować postulat jednolitości i niesprzeczności polskiego systemu prawnego, należałoby włączyć w skład pojęcia martwego urodzenia także poronienie. Rozgraniczenie czasowe ogólnego pojęcia martwego urodzenia kreowałoby podział na martwe urodzenie dziecka po 22 tygodniu ciąży (czyli w pierwszym dniu 23 tygodnia ciąży) i poronienie przed 22 tygodniem ciąży (do 21 tygodnia ciąży i końca 7 dnia). Taki stan rzeczy nie powodowałby nieścisłości na gruncie aktów stanu cywilnego.

\section{Bibliografia}

Darmorost E., Ustawa o cmentarzach i chowaniu zmartych. Komentarz, Warszawa 2014.

Drembkowski P., Ustawa o cmentarzach i chowaniu zmartych. Komentarz, Warszawa 2018.

Dziecko martwo urodzone - czynności prawne, http://www.sluzew.dominikanie. pl/rodzice_dziecka_utraconego/img/dziecko_martwo_urodzone_czynnosci_ prawne.pdf.

Fąk J., Zarodek, płód, od kiedy człowiek? [w:] Aborcja w ujęciu prawa, medycyny i psychologii, D. Franków (red.), Siedlce 2005.

Haberko J., Konsekwencje prawne żywego i martwego urodzenia, „Prawo i Medycyna” 2007, nr 3.

Hołub G., Godność osobowa dziecka nienarodzonego, http://bc.upjp2.edu.pl/Content/1756/holub-grzegorz.pdf.

Jaśkowski M., Konsekwencje prawne Protokołu nr 30 w sprawie stosowania Karty praw podstawowych Unii Europejskiej do Polski i Zjednoczonego Królestwa, „Zeszyty Prawnicze" 2013, nr 4 (40).

Kania A., Nasciturus pro iam nato habetur... dziecko (nasciturus) czy kobieta? Przesłanki przerwania ciąży w kontekście praw człowieka - analiza prawna [w:] Powszechny system ochrony praw człowieka 70 lat po proklamowaniu Powszechnej Deklaracji Praw Człowieka. Osiagnięcia - bariery - nowe wyzwania i rozwiązania, J. Jaskiernia, K. Spryszak (red.), Toruń 2019.

Lewandowska-Malec I., Dobra osobiste, wyd. 2, Warszawa 2017, Legalis.

Michajlik A., Ramotowski W., Anatomia i fizjologia człowieka, Warszawa 2015.

Michałowska K., Niemajątkowe wartości życia rodzinnego w polskim prawie cywilnym, Warszawa 2017, Legalis.

Radwański Z., Olejniczak A., Prawo cywilne - czesść ogólna, Warszawa 2017.

Smyczyński T., Prawo rodzinne i opiekuńcze, Warszawa 2016.

Zubik M., Ochrona prawna początku życia człowieka w rozwiązaniach międzynarodowych i konstytucyjnych w Europie, „Przegląd Sejmowy” 2007, nr 3 (80). 
Stanowisko Zespołu Prawnego ws. wymogów karty martwego urodzenia Federacji na rzecz Kobiet i Planowania Rodziny, http://federa.org.pl/karta-martwego-urodzenia/.

\section{Akty prawne i dokumenty urzędowe}

Powszechna Deklaracja Praw Człowieka z 10 grudnia 1948 r., http://www.unesco. pl/fileadmin/user_upload/pdf/Powszechna_Deklaracja_Praw_Czlowieka.pdf.

Konwencja o Ochronie Praw Człowieka i Podstawowych Wolności sporządzona w Rzymie dnia 4 listopada 1950 r., zmieniona następnie Protokołami nr 3, 5 i 8 oraz uzupełniona Protokołem nr 2, Dz.U. z 1993 r. Nr 61, poz. 284.

Międzynarodowy Pakt Praw Obywatelskich i Politycznych otwarty do podpisu w Nowym Jorku dnia 19 grudnia 1966 r., Dz.U. z 1977 r. Nr 38, poz. 167.

Karta Praw Podstawowych Unii Europejskiej, Dz.Urz. UE z 2016 r. C 202, s. 389.

Konstytucja Rzeczypospolitej Polskiej z dnia 2 kwietnia 1997 r., Dz.U. Nr 78, poz. 483 ze zm.

Ustawa z dnia 31 stycznia 1959 r. o cmentarzach i chowaniu zmarłych, tekst jedn.: Dz.U. z 2019 r. poz. 1473 ze zm.

Ustawa z dnia 25 lutego 1964 r. - Kodeks rodzinny i opiekuńczy, tekst jedn.: Dz.U. z 2017 r. poz. 682 ze zm.

Ustawa z dnia 23 kwietnia 1964 r. - Kodeks cywilny, tekst jedn.: Dz.U. z 2019 r. poz. 1145 ze zm.

Ustawa z dnia 29 września 1986 r. - Prawo o aktach stanu cywilnego, tekst jedn.: Dz.U. z 2018 r. poz. 2224 ze zm.

Ustawa z dnia 7 stycznia 1993 r. o planowaniu rodziny, ochronie płodu ludzkiego i warunkach dopuszczalności przerywania ciąży, Dz.U. Nr 17, poz. 78 ze zm.

Rozporządzenie Ministra Zdrowia z dnia 21 grudnia 2010 r. w sprawie rodzajów i zakresu dokumentacji medycznej oraz sposobu jej przetwarzania, Dz.U.Nr 252, poz. 1697 ze zm.

Rozporządzenie Ministra Zdrowia z dnia 9 listopada 2015 r. w sprawie rodzajów, zakresu i wzorów dokumentacji medycznej oraz sposobu jej przetwarzania, Dz.U. poz. 2069.

Druk sejmowy nr 3941 Sejmu RP VI kadencji z 19.01.2011 r., http://orka.sejm.gov. pl/Druki6ka.nsf/0/BAC0DF460FF65CCDC1257849003B7988/\$file/3941.pdf.

\section{Orzecznictwo}

Orzeczenie TK z dnia 28 maja 1997 r., K 26/96, Legalis nr 10361.

Wyrok SN z dnia 9 grudnia 2011 r., III CSK 106/11, Legalis nr 429214.

Wyrok SN z dnia 3 grudnia 2010 r., I CSK 66/10, Legalis nr 414109.

Wyrok Sądu Apelacyjnego w Rzeszowie z dnia 25 października 2012 r., I ACa 352/12, http://orzeczenia.ms.gov.pl.

Wyrok Sądu Okręgowego w Piotrkowie Trybunalskim z dnia 27 listopada 2011 r., I C 1760/13, http://orzeczenia.ms.gov.pl.

Wyrok Sądu Rejonowego dla Warszawy Pragi-Południe z dnia 17 lutego 2016 r., VI U 462/15, http://orzeczenia.ms.gov.pl. 
Przed nowelizacją ustawy o cmentarzach i chowaniu zmarłych z 2011 r. znacząco utrudniony był pochówek dzieci martwo urodzonych. Przyczyną tego problemu był niejasny stan prawny. Wynikał on z nierelewantnych przepisów dotyczących dokumentacji medycznej i aktów stanu cywilnego, utrudniających pochówek dzieci martwo urodzonych przed 22 tygodniem ciąży. Celem niniejszego opracowania była historyczna i dogmatyczna analiza regulacji administracyjnoprawnej pochówku dziecka utraconego, co pozwoliło na rozstrzygnięcie problemu statusu prawnego nasciturusa $\mathrm{w}$ ujęciu przedmiotowym lub podmiotowym w kontekście prawa do grobu. Sformułowano postulaty de lege ferenda w zakresie zmiany zakresu pojęć dotyczących śmierci dziecka poczętego, aby zrealizować dyrektywę spójności polskiego systemu prawnego. Całościowa analiza tworzy podstawę do zaproponowania zmian statusu prawnego nasciturusa przez wprowadzenie definicji dziecka poczętego, a co za tym idzie objęcie wprost ochroną także dziecka martwo urodzonego i instytucji chroniących jego prawa (rozszerzenia zadań kuratora ustanawianego na mocy art. 182 k.r.o.).

Słowa kluczowe: prawo do pochówku, nasciturus, prawa człowieka, dziecko martwo urodzone

\section{The Right to Burial of Unborn Children in the Light of Human Rights}

Abstract

Before the amendment of the Act on cemeteries and burial of the dead, it was difficult to bury stillborn children due to unclear legal status resulting from irrelevant provisions regarding medical and civil status records. This state of affairs made the burial of stillborn children before 22nd week of pregnancy difficult. The purpose of the article is a historical and dogmatic analysis of the administrative regulation of the burial of unborn children, hopefully facilitating the resolution of the issue of the legal status of the nasciturus in terms of the subjective and human approach in the context of the right to the grave. The article helps formulate de lege ferenda postulates as regards changing the concepts surrounding the death of the unborn child. All this to implement the directive of the cohesive Polish legal system. The comprehensive analysis will provide the basis for proposing changes in the legal status of the nasciturus by introducing the definition of a conceived child, and thus protecting the stillborn child and institutions protecting his/her rights (e.g. institution of the nasciturus curator established by Article 182 of the Polish Family and Guardianship Code).

Keywords: right to burial, nasciturus, human rights, stillborn child 